\title{
SISTEM PENGENALAN HURUF BAHASA ISYARAT MENGGUNAKAN ADAPTIVE LEARNING VECTOR QUANTIZATION
}

\author{
Ariadi Retno Tri Hayati Ririd ${ }^{1}$, Yoppy Yunhasnawa ${ }^{2}$, Yusliana Gadis Buata ${ }^{3}$ \\ ${ }^{1,2}$ Program Studi Teknik Informatika, Jurusan Teknologi Informasi, ${ }^{3}$ Politeknik Negeri Malang \\ 1faniri4education@gmail.com, ${ }^{2}$ yunhasnawa@gmail.com, ${ }^{3}$ yuslianagadis@gmail.com
}

\begin{abstract}
Abstrak
Para tuna rungu dan tuna wicara menggunakan komunikasi non verbal dalam berkomunikasi. Komunikasi ini menggunakan bahasa isyarat baik berupa gerakan isyarat tangan, isyarat tubuh dan ekspresi wajah. Agar dapat mengerti bahasa isyarat diperlukan suatu media komunikasi penerjemah bahasa isyarat tersebut menjadi bahasa verbal yang mudah dipahami. Dalam upaya memudahkan komunikasi orang tuna rungu dan tuna wicara dengan orang normal di SLB Islam Yasindo Malang dibuatlah sistem pengenalan huruf bahasa isyarat untuk membantu menerjemahkan citra tangan huruf bahasa isyarat menjadi tulisan alfabet.

Tahapan yang dilakukan dalam implementasi sistem pengenalan huruf bahasa isyarat ini adalah dengan membedakan objek dan background dari citra tangan untuk menentukan citra yang mencerminkan huruf Sistem Isyarat Bahasa Indonesia (SIBI). Citra tangan dimuat dari direktori kemudian dilakukan proses preprocessing, pelatihan data dan klasifikasi tangan. Metode klasifikasi yang digunakan dalam pengenalan huruf bahasa isyarat tangan ini menggunakan metode Learning Vector Quantization with Adaptive Prototype Addition and Removal.

Sistem ini dapat mengenali 24 huruf bahasa isyarat yang ditargetkan. Berdasarkan hasil dari perancangan dan pengujian sistem pada penelitian ini, persentase akurasi baca huruf terbaik adalah sebesar $88,75 \%$. Hasil dari pengenalan ini dipengaruhi oleh proses validasi, teknik pengambilan citra dan faktor pencahayaan.
\end{abstract}

Kata kunci : huruf bahasa isyarat SIBI, Preprocessing, Learning Vector Quantization

\section{Pendahuluan}

Komunikasi bahasa isyarat merupakan metode komunikasi pokok penderita tuna rungu wicara dimana menggunakan orientasi bentuk dan gerakan tangan serta ekspresi wajah untuk mengungkapkan pikiran mereka. Komunikasi ini terkadang masih menyulitkan mereka untuk berkomunikasi dengan orang normal yang belum mengenal bahasa isyarat.

Dalam rangka memperkenalkan huruf bahasa isyarat pada orang normal di SLB Islam Yasindo Malang, dibuatlah sistem pengenalan huruf Bahasa isyarat dengan menggunakan metode Adaptive Learning Vector Quantization dimana citra tangan sebagai masukannya. Sistem ini dibuat dengan mengacu pada SIBI (Sistem Isyarat Bahasa Indonesia).

LVQ adalah algortima klasifikasi yang memanfaatkan vektor yang terhubung dan bekerja secara kompetitif namum terbimbing untuk menyelesaikan suatu masalah. Kusumadewi, S. (2003). Adaptive LVQ merupakan modifikasi yang memperbaiki kinerja metode klasifikasi LVQ. Adaptive LVQ merupakan cara mengolah data training dengan menggunakan dua metode yaitu LVQAdd untuk menambahkan data yang berpotensi menguntungkan dan LVQRemove untuk mengurangi data yang kurang baik. Grbovic, M. et al (2009).

Penelitian ini dilakukan dengan menggunakan 24 huruf bahasa isyarat (A-Z) kecuali J dan Z. Citra yang digunakan adalah citra tangan tampak depan dan diasumsikan tanpa noise dan citra berwarna dalam format JPEG.

\section{Landasan Teori}

Sebanyak 576 citra tangan yang didapatkan dari 8 orang digunakan dalam penelitian ini, 96 citra digunakan untuk data training dan 480 citra digunakan untuk data testing.

\subsection{Skin Detection}

Citra tangan yang dimuat dari direktori dilakukan proses deteksi kulit untuk dapat membedakan bagian citra yang merupakan kulit dan bukan kulit. Aturan yang digunakan adalah ruang warna RGB seperti dua persamaan berikut. $(R>95) A N D(G>40) A N D(B>20)$ $A N D(\max \{R, G, B\}-\min \{R, G, B\}>$ 
$(|R-G|>15) A N D(R>G) A N D(R>B)$

$(R>220) A N D(G>210) A N D(B>170)$

$A N D(|R-G| \leq 15) A N D(R>B) A N D(G$

$>B)$

Melalui proses ini bagian citra tangan yang merupakan kulit pikselnya diubah menjadi 1 (putih) dan bukan kulit menjadi 0 (hitam). Peer, P. et al (2003).

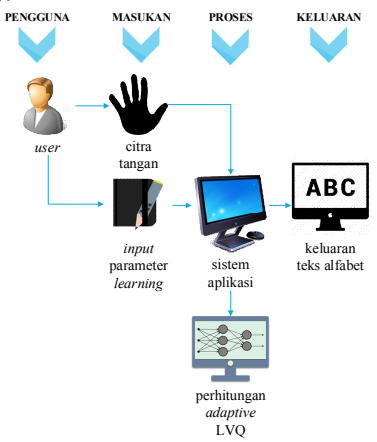

Gambar 1. Arsitektur Sistem Pengenalan Huruf Bahasa Isyarat

\subsection{Adaptive LVQ Training}

Citra hasil preprocessing kemudian digunakan dalam proses training dengan menggunakan algoritma adaptive LVQ. Proses training ini akan menghasilkan bobot akhir untuk tiap huruf yang nantinya digunakan dalam tahap klasifikasi pengenalan huruf bahasa isyarat. Citra yang digunakan dalam tahap ini sebanyak 576 citra tangan dimana 96 citra digunakan untuk data training dan 480 citra digunakan untuk data testing.

Algoritma pembelajaran Adaptive LVQ dimulai dengan melakukan inisialisasi terhadap beberapa parameter seperti epoch, nilai learning rate, dan vektor bobot awal. Kemudian proses training LVQ dijalankan dengan diikuti proses validation kemudian testing untuk tahap pengenalan citra tangan. Grbovic, M. et al (2009). Pada algoritma Adaptive LVQ untuk mencari jarak terdekat digunakan rumus jarak Euclidean yaitu:

$\left\|\mathrm{x}-\mathrm{w}_{\mathrm{j}}\right\|$

Yang kemudian dilanjutkan dengan perhitungan bobot baru menggunakan rumus:

Jika $\mathrm{T}=\mathrm{C}_{\mathrm{j}}$ maka:

$\mathrm{w}_{\mathrm{j}}($ baru $)=\mathrm{w}_{\mathrm{j}}($ lama $)+\alpha\left(\mathrm{x}-\mathrm{w}_{\mathrm{j}}(\right.$ lama $\left.)\right)$

Jika $\mathrm{T}=\mathrm{C}_{\mathrm{j}}$ maka:

$\mathrm{w}_{\mathrm{j}}($ baru $)=\mathrm{w}_{\mathrm{j}}($ lama $)-\alpha\left(\mathrm{x}-\mathrm{w}_{\mathrm{j}}(\right.$ lama $\left.)\right)$

Keterangan notasi:

$\mathrm{x} \quad$ : Vektor input.

$\mathrm{w}_{\mathrm{j}}$ : Vektor bobot.

$\mathrm{C}_{\mathrm{j}} \quad$ : Kategori yang diwakilkan oleh output ke-j.

$\alpha \quad$ : Learning rate.

$\mathrm{T}$ : Kategori yang benar untuk vektor training.
Sehingga menghasilkan bobot baru yang akan digunakan dalam proses validation dan testing. Kusumadewi, Sri (2003).

\section{Metodologi Penelitian}

Metode penelitian yang digunakan dalam penelitian ini terdiri dari identifikasi masalah, studi literatur, analisa kebutuhan, pengumpulan data, perancangan sistem, implementasi sistem, pengujian dan analisis serta pengambilan kesimpulan dan saran. Berikut Gambar 2 diagram alir metode penelitian yang dilakukan.

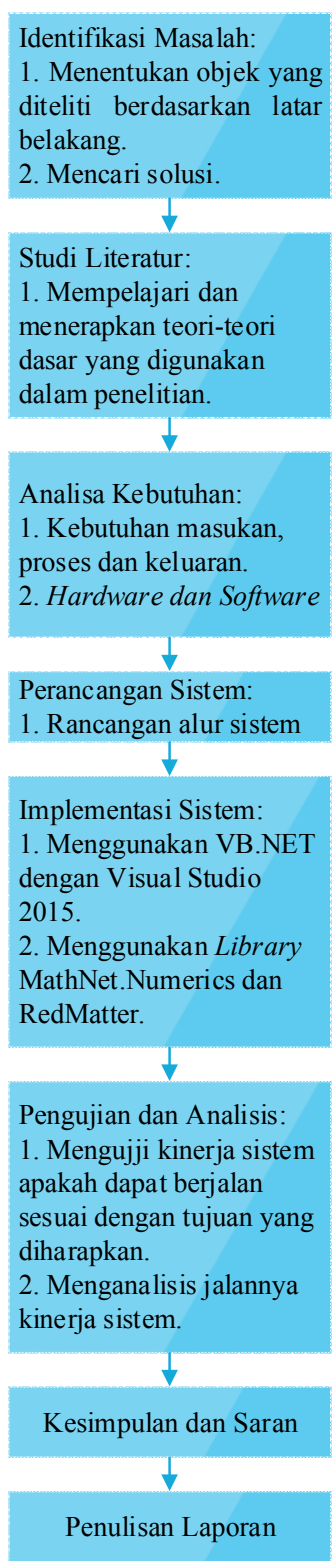

Gambar 2. Diagram Alir Metode Penelitian

\section{Analisis dan Perancangan}

Perancangan diagram alur sistem menggambarkan bagaimana sistem bekerja untuk 
melakukan pengenalan huruf bahasa isyarat. Rancangan alur sistem yang diimplementasikan seperti Gambar 3 berikut.

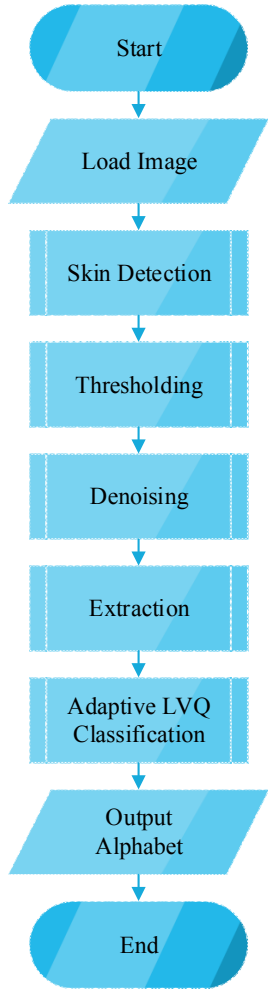

Gambar 3. Flowchart Sistem Pengenalan Huruf Bahasa Isyarat

\section{Impelementasi}

Implementasi sistem pengenalan huruf bahasa isyarat ini didasarkan pada pembahasan bab analisis dan perancangan sebelumnya, sehingga menghasilkan tampilan sistem seperti pada gambar-gambar berikut ini.

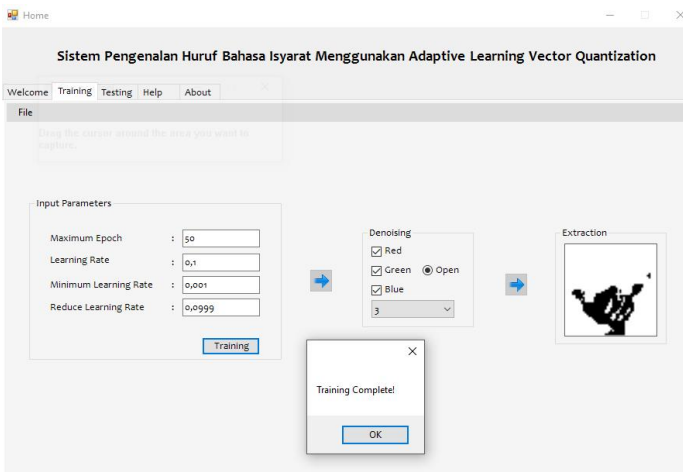

Gambar 4. User Interface Training Page

Pada halaman training, dimasukkan masukan parameter yang dibutuhkan. Parameter ini nantinya akan mempengaruhi hasil akurasi pada proses testing.

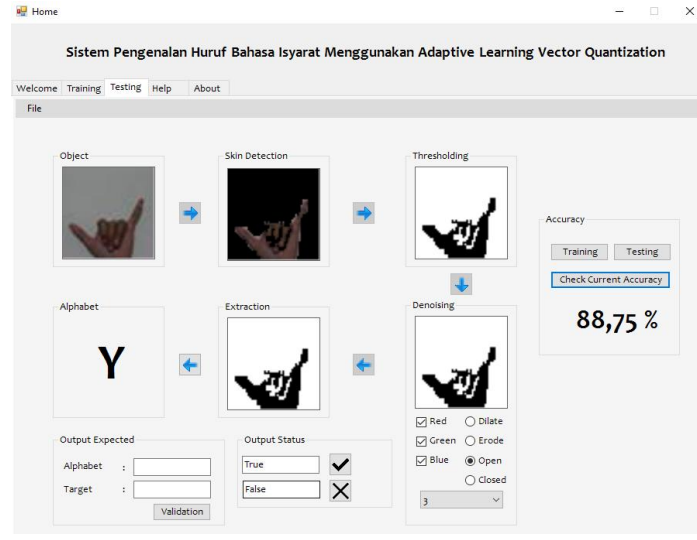

Gambar 5. User Interface Testing Page

\section{Pengujian dan Pembahasan}

Proses pengujian dilakukan terhadap beberapa macam pengaruh perhitungan akurasi dari sistem dalam melakukan pengenalan, antara lain:

a. Pengaruh penggunaan ekstraksi ciri Fitur Biner.

b. Pengaruh penggunaan perhitungan jarak Euclidean pada algoritma Adaptive LVQ.

c. Pengaruh proses validasi (Adaptive Prototype Addition and Removal) dan banyaknya jumlah set data testing yang digunakan (n set x 24 kelas huruf).

Tabel 1. Hasil Testing Pengaruh Jumlah Set Data

\begin{tabular}{|c|c|}
\hline Jumlah Data Testing (n set) & Akurasi (\%) \\
\hline $96(4$ set) & $84,38 \%$ \\
\hline $192(8$ set) & $82,82 \%$ \\
\hline $288(12$ set) & $85,42 \%$ \\
\hline $384(16$ set $)$ & $87,50 \%$ \\
\hline $480(20$ set) & $88,75 \%$ \\
\hline
\end{tabular}

\section{Kesimpulan dan Saran}

\subsection{Kesimpulan}

Hasil pengujian akurasi algoritma Adaptive Learning Vector Quantization pada proses testing data citra tangan huruf bahasa isyarat terhadap pengaruh proses validasi (Adaptive Prototype Addition and Removal) dan jumlah data testing didapatkan hasil akurasi terbaik ketika jumlah data testing sebanyak $480 \quad(20$ set $)$ dengan persentase sebesar $88,75 \%$.

\subsection{Saran}

Berdasarkan hasil dari penelitian ini, saran yang ditunjukkan untuk penelitian selanjutnya yaitu mengenai peningkatan kestabilan teknik pengambilan citra huruf bahasa isyarat antara lain faktor posisi tangan dan pencahayaan. Selain itu pengembangan metode thresholding dan deteksi bentuk citra tangan untuk meminimalisir kesalahan klasifikasi serta sistem dapat mengenali huruf isyarat dinamis, seperti huruf J dan Z. 
Volume 4, Edisi 2, Februari 2018

\section{Daftar Pustaka:}

Grbovic, Mihajlo, et al, (2009), Learning Vector

Quantization with Adaptive Prototype Addition and Removal, Department of Computer and Information Sciences, Temple University, Philadelphia.

Kusumadewi, Sri, (2003), Artificial Intelligence (Teknik dan Aplikasinya), Yogyakarta: GRAHA ILMU.

Kovac, J., Peer, P., Solina, F, (2003), Human Skin Colour Clustering for Face Detection, EUROCON, University of Ljubljana, Ljubljana, Slovenia. 